Original Research Article

\title{
A short term evaluation of effect on serum urea, creatinine and potassium levels with use of angiotensin II receptor blockers (olmesartan or telmisartan) in stage 1 hypertensive patients
}

\author{
Varun Gupta ${ }^{1}$, Pooja Singh ${ }^{2} *$
}

\begin{abstract}
${ }^{1}$ Department of Pharmacology,
${ }^{2}$ Department of Pathology, Government Medical College, Bharartpur, Rajasthan, India
\end{abstract}

Received: 02 August 2019

Revised: 12 September 2019

Accepted: 13 September 2019

\section{*Correspondence to: \\ Dr. Pooja Singh, \\ Email: poojasingh7march@ yahoo.co.in}

Copyright: (C) the author(s), publisher and licensee Medip Academy. This is an openaccess article distributed under the terms of the Creative Commons Attribution NonCommercial License, which permits unrestricted noncommercial use, distribution, and reproduction in any medium, provided the original work is properly cited.

\begin{abstract}
Background: Angiotensin-converting enzyme inhibitors and angiotensin II receptor blockers (ARBs) are being used as first line agents for the treatment of hypertension in haemodialysis patients as well as in the general population. Serious hyperkalemia is common in patients with end-stage renal disease, and is observed in about $10 \%$ of haemodialysis patients. Although many research have been done so far to compare the antihypertensive efficacy of ARBs, but such studies to evaluate the effect on serum urea, creatinine and potassium levels are not so common in North India region.

Methods: In this open label, prospective, randomized study, we evaluated the effect on serum urea, creatinine and potassium levels with use of ARB's (olmesartan or telmisartan) in stage 1 hypertensive patients (JNCVII). 60 patients were randomized in to two groups. The odd numbers will be allotted olmesartan $20 \mathrm{mg}$ (group A) and even numbers to telmisartan $40 \mathrm{mg}$ (group B). Impacts on serum urea, creatinine and potassium levels were evaluated after 12 weeks.
\end{abstract}

Results: Our results indicates that there was no statistically significant alterations in mean serum creatinine, blood urea and in mean serum potassium levels compared to baseline within the two groups as well as when mean of both groups were compared, olmesartan showed a better reduction in blood pressure as compared to telmisartan.

Conclusions: Olmesartan showed a better reduction in blood pressure with similar effects in biochemical parameters as telmisartan.

Keywords: Olmesartan, Telmisartan, Mean serum creatinine, Blood urea, Mean serum potassium

\section{INTRODUCTION}

Hypertension is a multifactorial disease affecting 1 billion people worldwide. It is the most common, readily identifiable and reversible risk factor for myocardial infarction, stroke, heart failure, atrial fibrillation, aortic dissection and peripheral arterial disease. ${ }^{1}$ Currently, high blood pressure (BP) causes about $54 \%$ of stroke and $47 \%$ of ischemic heart disease worldwide. ${ }^{2}$

The renin angiotensin system (RAS) plays an important role in the pathophysiology of cardiovascular disease.
Modulation of renin angiotensin aldosterone system (RAAS) with angiotensin-converting enzyme (ACE) inhibitors, angiotensin II receptor blockers (ARB) and aldosterone inhibitors reduces a range of adverse cardiovascular outcomes in patients with or at risk of cardiovascular disease. Large number of pharmacological agents belonging to different classes and groups are being used for the management of hypertension. Agents modifying RAAS particularly ACE inhibitors and ARBs are being used as first line anti-hypertensive agents in the management of hypertension. Renin-angiotensin system blockade exerts potent ant atherosclerotic effects, which 
are mediated by their antihypertensive, anti-inflammatory and proliferative and oxidative stress lowering properties. Inhibitors of the system- that is, angiotensin converting enzyme inhibitors and angiotensin receptor blockers are now first-line treatments for hypertensive target organ damage and progressive renal disease.

Among the several ARBs available in the clinical setting, olmesartan is thought to have a significantly stronger blood pressure lowering effect than losartan or valsartan with their respective starting doses. ${ }^{3}$

Serious hyperkalemia is common in patients with endstage renal disease (ESRD) and is observed in about $10 \%$ of haemodialysis patients. ${ }^{4}$ One group of investigators reported that hyperkalemia, besides congestive heart failure, was the most common indication requiring interventional extra-haemodialysis in an emergency department for ESRD patients on maintenance haemodialysis. ${ }^{5}$

Therefore, the prevention of life-threatening hyperkalemia is one of the main goals of haemodialysis. Aside from dietary indiscretion, there are few known major risk factors for the development of hyperkalemia in maintenance haemodialysis patients, such as prolonged fasting, hyperglycemia and medications that might affect potassium homeostasis. Medications generally produce hyperkalemia either by causing redistribution of potassium or by impairing renal potassium excretion. ${ }^{6}$

ACEIs and ARBs are thought to have greater cardioprotective effects than other groups of antihypertensive drugs in haemodialysis patients as well as in the general population. ${ }^{7,8}$ Therefore, the use of ACEIs or ARBs is often recommended as a first line of treatment in the majority of patients on maintenance haemodialysis. ${ }^{9}$ However, patients with chronic renal disease are at increased risk of hyperkalemia, and ACEIs can exacerbate the hyperkalemia. This increase in serum potassium necessitated the discontinuation of ACEI in $1.2-1.6 \%$ of subjects in clinical trials. ${ }^{10}$ Therefore, hyperkalemia limits the use of ACEIs in a patient population that could otherwise derive significant benefit. Knowledge of ACEI and ARB influences on serum potassium concentrations results from clinical trials that compare an ACE inhibitor with an ARB on renal function in people with heart failure. These trials demonstrated a significantly lower incidence of hyperkalemia in patients randomly assigned to an ARB treatment compared with those undergoing ACEI treatment. ${ }^{11,12}$

In contrast with those patients before the start of maintenance haemodialysis, RAS blockades are not likely to have major effects on the serum potassium levels in patients on maintenance dialysis because the removal of potassium is achieved mainly by haemodialysis and renal excretion plays a minor role in those patients. Because only few studies have investigated the effect of ACEIs and ARBs on serum potassium in patients on maintenance dialysis, the risk of hyperkalemia from ACEI and ARB in haemodialysis patients is unclear. ${ }^{13,14}$

Bakris et al reviewed 12 randomized clinical trials that evaluated renal disease progression among patients with preexisting renal insufficiency. Six of these studies were multicenter, double-blinded, and placebo controlled, with the remainder being smaller randomized studies with a minimum 2-year follow-up on renal function. These investigations evaluated patients with and without diabetes or systolic heart failure. Average duration of follow-up for all studies was 3 years. A strong association exists between acute increases in serum creatinine of up to $30 \%$ that stabilize within the first 2 months of ACEI therapy and long-term preservation of renal function.

In this study we will evaluate the short term effect of ARB's (telmisartan $40 \mathrm{mg} /$ day vs olmesartan $20 \mathrm{mg}$ /day in a single daily dose) in stage 1 hypertensive patients (as per JNCVII), on serum urea, creatinine and potassium levels in patients attending Medicine Outdoor Department of Rohilkhand Medical College and Hospital, Bareilly region.

RAS blockers, ACEIs and ARBs are well accepted for the cardio renal-protective benefits added to antihypertensive effects in chronic kidney diseases (CKD), but is found to be associated with an increased risk of hyperkalemia. However, few studies have investigated the effect of RAS blockades on serum potassium in dialysis patients.

Although many research have been done so far to compare the antihypertensive efficacy of ARBs, but such studies to evaluate the effect on serum urea, creatinine and potassium levels are not so common in Bareilly region.

Therefore, in the present study, we were interested to evaluate the effect of ARB's (telmisartan $40 \mathrm{mg} /$ day vs olmesartan $20 \mathrm{mg} /$ day in a single daily dose) in stage 1 hypertensive patients (as per JNCVII), on serum urea, creatinine and potassium levels

\section{Objectives}

The objectives of the present study was to evaluate the effect of ARB's (telmisartan $40 \mathrm{mg}$ /day vs olmesartan 20 $\mathrm{mg}$ /day in a single daily dose) in stage 1 hypertensive patients (as per JNCVII), on serum urea, creatinine and potassium levels in a short term study.

\section{METHODS}

A prospective randomized interventional open label observational comparative clinical study of 3 months duration from December 2014 to February 2015 was conducted amongst the patients attending the medicine outdoor patient department of Rohilkhand Medical 
College and Hospital, Bareilly diagnosed as hypertension (JNC VII stage 1). Written informed consent from all the participants was undertaken before starting the study and the participants were free to withdraw without prejudice at any time. The study protocol was approved by institutional ethical committee. Participants were randomized into 2 groups. The odd numbers will be allotted olmesartan (group A) and even numbers to telmisartan (group B).

\section{Inclusion criteria}

All patients of both the genders, aged 30 to 80 years of stage 1 hypertension will be included in the study.

\section{Exclusion criteria}

Patient of age group less than 30 and more than 80 years. The subjects with presence of history of any acute or chronic disease that would affect the study variables will be excluded. Patients with history of diabetes mellitus, known hypersensitivity to angiotensin receptor, uncontrolled hypertension (BP >160/100 mm Hg), patients on other anti-hypertensive therapy, secondary hypertension and of significant cardiovascular disease were also excluded from the study. Pregnant and lactating females, significant renal disease (serum creatinine $>2$ $\mathrm{mg} / \mathrm{dl}$ ), significant liver disease (SGOT and SGPT >2 times the normal values), known hypersensitivity to angiotensin receptor blocker, inability to tolerate olmesartan or telmisartan and chronic use of corticosteroids, NSAIDs and/or sex hormones like oral contraceptives pills were excluded from the study.
Enrolled patients under treatment were subsequently monitored, investigated and reassessed at regular intervals as below for evaluation of BP control and monitoring of serum urea, creatinine and potassium levels 2 weeks, 1 month, 2 months and 3 months.

The olmesartan treated group received olmet-20 (micro) and the telmisartan treated group received arbitel-40 (micro). Doses of anti-hypertensive were fixed throughout the study period and no upward titration of doses was done. All patients recruited in the study were asked question based on structured pretested and predesigned questionnaire.

\section{Investigations}

Baseline investigations for serum creatinine, serum $\mathrm{k}+$ levels, blood urea was done and the same tests were repeated at end of study i.e., after 3 months.

The data obtained were statistically analyzed by paired and unpaired t-test using SPSS software version 23 and Microsoft Office Excel 2007, p<0.05 was taken as significant.

\section{RESULTS}

Table 1 shows the demographic characteristic of the patients enrolled in the study in which differences were found to be statistically not significant in both the groups. Hence both olmesartan and telmisartan treated groups were comparable with respect to age $(p=0.7472)$, sex $(\mathrm{p}=0.6056)$, locality $(\mathrm{p}=0.3006)$, education $(\mathrm{p}=0.1205)$ and socio-economic status $(\mathrm{p}=0.0384)$.

Table 1: Demographic characteristics.

\begin{tabular}{|c|c|c|c|c|}
\hline Characteristic & Group A (olmesartan) & Group B (telmesartan) & P value & Significance \\
\hline Age & $52.6 \pm 10.59$ & $51.8 \pm 8.42$ & 0.7472 & NS \\
\hline \multicolumn{5}{|l|}{ Sex } \\
\hline Male & 16 & 14 & \multirow{2}{*}{0.6056} & \multirow{2}{*}{ NS } \\
\hline Female & 14 & 16 & & \\
\hline \multicolumn{5}{|l|}{ Locality } \\
\hline Ruler & 14 & 12 & \multirow{2}{*}{0.3006} & \multirow{2}{*}{ NS } \\
\hline Urban & 16 & 18 & & \\
\hline \multicolumn{5}{|l|}{ Education } \\
\hline Illiterate & 11 & 17 & \multirow{2}{*}{0.1205} & \multirow{2}{*}{ NS } \\
\hline Literate & 19 & 13 & & \\
\hline \multicolumn{5}{|c|}{ Socio-economic status } \\
\hline Lower & 1 & 0 & \multirow{5}{*}{0.0384} & \multirow{5}{*}{ Significant } \\
\hline Lower middle & 7 & 3 & & \\
\hline Upper & 2 & 0 & & \\
\hline Upper lower & 9 & 20 & & \\
\hline Upper middle & 11 & 7 & & \\
\hline
\end{tabular}

It also depicts the comparative evaluation of diastolic blood pressure (DBP) between the two groups. The baseline valves of DBP for both the groups were statistically comparable. There was statistically significant decrease $(\mathrm{p}=0.0296)$ in DBP in Group A as compared to Group B as early as $2^{\text {nd }}$ week of pharmacotherapy with olmesartan and telmisartan which continued to be significant at 1 month $(\mathrm{p}=0.0450), 2^{\text {nd }}$ 
month $(\mathrm{p}=0.0349)$ and at the end point $3^{\text {rd }}$ month $(\mathrm{p}=0.047)$.

Table 2 shows that laboratory parameters, mean serum creatinine, mean blood urea, mean serum potassium, at baseline were $1.15,29.87,3.74 \mathrm{mg} / \mathrm{dL}$, respectively. At last follow up these values were 1.14, 30.25, 3.78, respectively. There was no statistically significant increase in, mean serum creatinine, blood urea and in mean serum potassium levels compared to baseline.

Table 2: Differences in biochemical parameters between Group A and Group B.

\begin{tabular}{|lllll|}
\hline & $\begin{array}{l}\text { Group A (olmesartan) } \\
\text { Mean } \pm \text { SD }\end{array}$ & $\begin{array}{l}\text { Group B (telmisartan) } \\
\text { Mean } \pm \text { SD }\end{array}$ & P value & Significance \\
\hline Serum-creatinine $(\mathbf{m g} \%)$ & & & \\
\hline Baseline & $1.15 \pm 0.29$ & $1.14 \pm 0.27$ & 0.8905 & NS \\
\hline 3 months & $1.14 \pm 0.28$ & $1.16 \pm 0.26$ & 0.7808 & NS \\
\hline P value & $0.9241(\mathrm{NS})$ & $0.1714(\mathrm{NS})$ & & \\
\hline Serum-urea (mg \%) & & & $\mathrm{NS}$ \\
\hline Baseline & $29.87 \pm 6.05$ & $31.07 \pm 6.77$ & 0.472 & $\mathrm{NS}$ \\
\hline 3 months & $30.25 \pm 5.09$ & $30.93 \pm 6.47$ & 0.6634 & \\
\hline P value & $0.7936(\mathrm{NS})$ & $0.7367(\mathrm{NS})$ & & $\mathrm{NS}$ \\
\hline Serum-K+(mmol/L) & & & $\mathrm{NS}$ \\
\hline Baseline & $3.74 \pm 0.21$ & $3.83 \pm 0.25$ & 0.1365 & \\
\hline 3 months & $3.78 \pm 0.183$ & $3.85 \pm 0.24$ & 0.2683 & \\
\hline P value & $0.3689(\mathrm{NS})$ & $0.4072(\mathrm{NS})$ & & \\
\hline
\end{tabular}

Table 3: Mean changes in blood pressure.

\begin{tabular}{|c|c|c|c|c|c|}
\hline \multicolumn{6}{|c|}{ Changes in blood pressure } \\
\hline \multirow[t]{2}{*}{ Visits } & $\begin{array}{l}\text { Group A (olmesartan) } \\
\text { BP (mmHg) }\end{array}$ & $\begin{array}{l}\text { Group B (telmesartan) BP } \\
\text { (mmHg) }\end{array}$ & \multirow[t]{2}{*}{ t value } & \multirow[t]{2}{*}{ P value } & \multirow[t]{2}{*}{ Significance } \\
\hline & Mean \pm SD & Mean \pm SD & & & \\
\hline \multicolumn{6}{|c|}{ Systolic blood pressure (SBP) } \\
\hline Baseline & $151.13 \pm 6.80$ & $150.7 \pm 5.26$ & 0.2740 & 0.7851 & NS \\
\hline $2^{\text {nd }}$ week & $141.48 \pm 5.39$ & $144.06 \pm 3.68$ & 2.1287 & 0.0345 & Significant \\
\hline 1 month & $137.5 \pm 5.18$ & $140.4 \pm 3.77$ & 2.4337 & 0.0175 & Significant \\
\hline 2 month & $134.9 \pm 5.44$ & $138.6 \pm 3.40$ & 3.1122 & 0.0029 & Significant \\
\hline 3 month & $133.1 \pm 5.60$ & $136.67 \pm 3.22$ & 2.9875 & 0.0037 & Highly significant \\
\hline \multicolumn{6}{|c|}{ Diastolic blood pressure (DBP) } \\
\hline Baseline & $91.3 \pm 4.29$ & $90.60 \pm 3.49$ & 0.6933 & 0.04909 & NS \\
\hline $2^{\text {nd }}$ week & $84.7 \pm 3.60$ & $86.6 \pm 2.97$ & 2.1817 & 0.0296 & Significant \\
\hline 1 month & $82.4 \pm 3.29$ & $84.17 \pm 3.40$ & 1.9927 & 0.0450 & Signficant \\
\hline 2 month & $81.4 \pm 2.70$ & $83.10 \pm 3.36$ & 2.0903 & 0.0349 & Signficant \\
\hline 3 month & $80.8 \pm 2.49$ & $82.07 \pm 2.36$ & 1.9297 & 0.0472 & Significant \\
\hline
\end{tabular}

Table 3 shows the mean changes in systolic blood pressure (SBP) from baseline to 3 month following treatment with olmesartan (Group A) versus telmisartan (Group B). Baseline mean values of SBP for both the groups were comparable $(\mathrm{p}=0.7851)$. From the $2^{\text {nd }}$ week onwards difference in reduction in SBP was significantly more in olmesartan treated group which becomes highly significant at $3^{\text {rd }}$ month of follow up $(p=0.03450 .0175$, 0.0029 and 0.0037 at $2^{\text {nd }}$ week, 1 month, 2 month and 3 months respectively).

\section{DISCUSSION}

In this study amongst biochemical parameters, there were no statistically significant change in serum creatinine, blood urea and serum potassium with the two regimens observed in this short duration study. Bakris et al study with minimum 2 years follow up on renal functions, shows increase in serum creatinine levels with the use of ACEI. ${ }^{15}$

In this study we compared the effects of olmisartan and telmisartan on biochemical parameters. Despite various types of ARBs are available, there are few studies which compared the effect on biochemical profile. We found no statistically significant alterations within the two groups as well as when mean of both groups were compared. Nakayana et al also observed no significant alteration in biochemical parameters which supported our observations. ${ }^{16}$ Amarender et al in their 12 week study 
observed no statistically signficant difference in FBS $(\mathrm{mg} / \mathrm{dl})$ serum urea $(\mathrm{mg} / \mathrm{dl})$ and serum creatinine $(\mathrm{mg} / \mathrm{dl})$ values when mean of the two groups were compared. ${ }^{25}$ This is in accordance with our findings. But there signficant decrease in serum urea and serum creatinine from baseline to end point with in the groups of olmesartan and telmisartan inhibitors which is contradictory with our study.

Serious hyperkalemia is common in patients with ESRD, and is observed in about $10 \%$ of hemodialysis patients. ${ }^{4}$ One group of investigators reported that hyperkalemia, besides congestive heart failure, was the most common indication requiring interventional extra-haemodialysis in an emergency department for ESRD patients on maintenance haemodialysis. ${ }^{5}$ Knowledge of ACEI and ARB influences on serum potassium concentrations results from clinical trials that compare an ACE inhibitor with an ARB on renal function in people with heart failure. These trials demonstrated a significantly lower incidence of hyperkalemia in patients randomly assigned to an ARB treatment compared with those undergoing ACEI treatment. ${ }^{11,12}$

In this study, olmesartan treated patients (Group A) showed statistically significant reduction both in SBP and DBP as compared to telmisartan (Group B) in all the follow-ups (SBP at 2 week, $\mathrm{p}=0.0345,1$ month, $\mathrm{p}=0.0175,2$ month, $\mathrm{p}>0.0029$ and 3 month, $\mathrm{p}=0.0296$ and 3 month $\mathrm{p}=0.0472$ ), Our findings are consistent with the study by Nakayama et al who observed that olmesartan lowered systolic, diastolic and mean blood pressure by 3.3, 2.7 and $3.1 \mathrm{~mm} \mathrm{Hg}$ more than that done by telmisartan $(\mathrm{p}=0.0305,0.0087$ and 0.0058 for SBP, DBP and mean BP respectively). ${ }^{16}$ Moreover, their data also reported that olmesartan at $20 \mathrm{mg}$ /day lowered $\mathrm{BP}$ more than telmisartan at $40 \mathrm{mg} /$ day. Further they observed that olmesartan therapy lowered mean systolic and diastolic $\mathrm{BP}$ to below $130 / 80 \mathrm{~mm} \mathrm{Hg}$ which is recommended by both JNC7 and ESH/ESC. ${ }^{17,18}$

\section{CONCLUSION}

Olmesartan showed a better reduction in blood pressure with similar effects in biochemical parameters as telmisartan.

\section{Limitation}

As this study was of 3 months duration, so long term results cannot be depicted. Therefore longer duration of study may be required to observe the effect of olmesartan and telmisartan on metabolic parameters and blood pressure.

\section{ACKNOWLEDGEMENTS}

Authors are thankful to their colleagues and seniors for their support and encouragement throughout their study period.
Funding: No funding sources

Conflict of interest: None declared

Ethical approval: The study was approved by the Institutional Ethics Committee

\section{REFERENCES}

1. Victor RG. Systemic Hypertension: Mechanism and diagnosis. In: Bonow Ro, Mann DL, Zipesd DP, Libby P, eds. Braunwald's Heart Disease: A Textbook of Cardiovascular Medicine. 9th ed. Philadelphia: Sauders Elsevier; 2011: 935-954.

2. Lawers CM, Hoorn VS, Rodgers A. International Society of Hypertension. Global burden of blood pressure-related disease. Lancet. 2008;371(9623):1513-8.

3. Oparil S, Williams D, Chrysant SG, Marbury TC, Neutel J. Comparative efficacy of olmesartan, losartan, valsartan, and irbesartan in the control of essential hypertension. J Clin Hypertens. (Greenwich) 2001;3:283-91, 318.

4. Tzamaloukas AH, Avasthi PS. Temporal profile of serum potassium concentration in nondiabetic and diabetic outpatients on chronic dialysis. Am J Nephrol. 1987;6(7):101-9.

5. Sacchetti A, Stuccio N, Panebianco P, Torres M. ED hemodialysis for treatment of renal failure emergencies. Am J Emerg Med. 1999;17:305-7.

6. Ahmed J, Weisberg LS. Hyperkalemia in dialysis patients. Semin Dial. 2001;14:348-56.

7. Canella G, Paoletti E, Delfino R, Peloso G, Rolla D, Molinari S. Prolonged therapy with ACE inhibitors induces a regression of left ventricular hypertrophy of dialyzed uremic patients independently from hypotensive effects. Am J Kidney Dis. 1997;30:65964.

8. Shibasaki Y, Masaki H, Nishiue T, Nishikawa M, Matsubara H, Iwasaka T. Angiotensin II type 1 receptor antagonist, losartan, causes regression of left ventricular hypertrophy in end-stage renal disease. Nephron. 2002;90:256-61.

9. K/DOQI Workgroup. K/DOQI clinical practice guidelines for cardiovascular disease in dialysis patients. Am J Kidney Dis. 2005;45:S1-53.

10. Bakris GL, Siomos M, Richardson D, Janssen I, Bolton WK, Hebert L, et al. ACE inhibition or angiotensin receptor blockade: impact on potassium in renal failure. VAL-K Study Group. Kidney Int 2000;58:2084-92.

11. Pitt B, Segal R, Martinez FA, Meurers G, Cowley AJ, Thomas I, et al. Randomised trial of losartan versus captopril in patients over 65 with heart failure (Evaluation of Losartan in the Elderly Study, ELITE). Lancet. 1997;349:747-52.

12. McKelvie RS, Yusuf S, Pericak D, Avezum A, Burns RJ, Probstfield J, et al. Comparison of candesartan, enalapril, and their combination in congestive heart failure: randomized evaluation of strategies for left ventricular dysfunction (RESOLVD) pilot study. The 
RESOLVD Pilot Study Investigators. Circulation. 1999;100:1056-64.

13. Knoll GA, Sahgal A, Nair RC, Graham J, van Walraven C, Burns KD. Renin-angiotensin system blockade and the risk of hyperkalemia in chronic hemodialysis patients. Am J Med. 2002;112:110-4.

14. Phakdeekitcharoen B, Leelasa-nguan P. Effects of an ACE inhibitor or angiotensin receptor blocker on potassium in CAPD patients. Am J Kidney Dis. 2004;44:738-46.

15. Bakris GL, Weir MR. Angiotensin-converting enzyme inhibitor-associated elevations in serum creatinine: is this a cause for concern?. Arch Intern Med. 2000;160(5):685-93.

16. Nakayama S, Watada H, Mita T, Ikeda F, Shimizu T, Uchino H, et al. Comparison of effects of olmesartan and telmisartan on blood pressure and metabolic parameters in Japanese early-stage type-2 diabetics with hypertension. Hypertens Res. 2008;31(1):7.

17. Chobanian AV, Bakris GL, Black HR, Cushman WC, Green LA, Izzo JL, et al. The Seventh Report of the Joint National Committee on Prevention, Detection, Evaluation, and Treatment of High Blood Pressure: the JNC 7 report. JAMA. 2003;289:2560-72.

18. 2003 European Society of Hypertension-European Society of Cardiology guidelines for the management of arterial hypertension. J Hypertens. 2003;21:101153.

Cite this article as: Gupta V, Singh P. A short term evaluation of effect on serum urea, creatinine and potassium levels with use of angiotensin II receptor blockers (olmesartan or telmisartan) in stage 1 hypertensive patients. Int J Basic Clin Pharmacol 2019;8:2328-33 